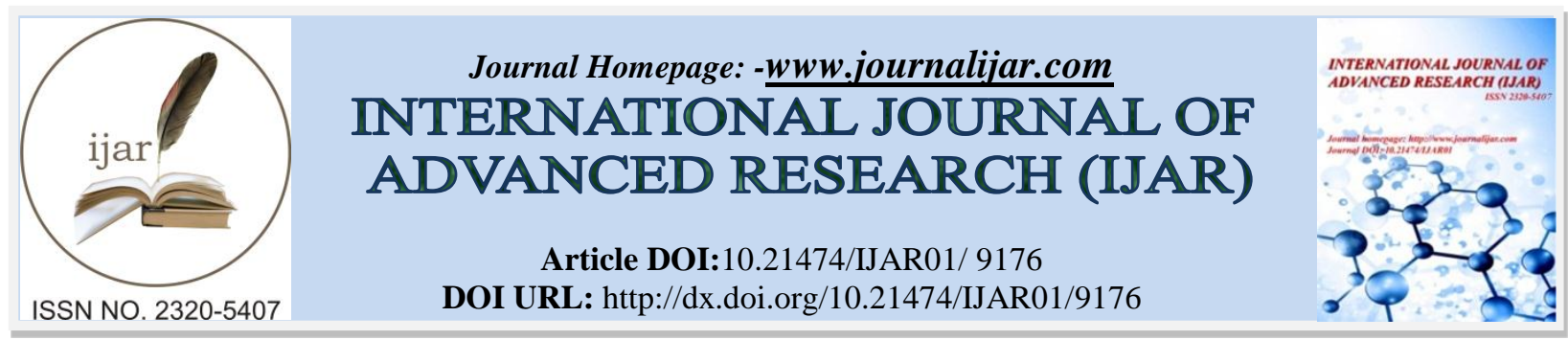

RESEARCH ARTICLE

\title{
SYNTHESIS OF NEW PYRAZOLO[3,4-D]PYRIMIDINE AND THEIR FUSED HETEROCYCLES.
}

\begin{abstract}
Aisha Youssef Hassan ${ }^{1}$, Anhar Abdel-Aziem ${ }^{1}$, Mona Abd-Elglil ${ }^{1}$ and Aisha Omar Hussain ${ }^{2}$. 1. Al-Azhar University, Faculty of Science, Girls ; Branch,Chemistry Department, Nasr City, Cairo, Egypt. 2. The High Institute of Engineering \&Technology, Basic Sciences Department, Al Tod -Luxor.
\end{abstract}

\section{Manuscript Info}

Manuscript History

Received: 26 March 2019

Final Accepted: 28 April 2019

Published: May 2019

\begin{abstract}
Novel pyrazolo[3,4-.]pyrimidine derivatives were synthesized via various synthetic pathways. Among which were different substituted pyrazole analogues that were synthesized, in addition to various fused dipyrazolo[1,5-c:4',3'-c]pyrimidine derivatives , imidazo[1,2$b]$ pyrazole and imidazo[1',2':3,4]imidazo[1,2-b]pyrazole derivatives .Besides pyrazolo[5,1- $b]$ quinazoline dervatives was also synthesized . The structure of the synthesized compounds were confirmed by IR, ${ }^{1} \mathrm{H}$ and ${ }^{13}$ CNMR, elemental analysis and mass spectra data and all structures of synthesized compounds agree with spectral data and elemental analysis.
\end{abstract}

Copy Right, IJAR, 2019,. All rights reserved.

\section{Introduction:-}

Pyrazolo pyrimidine and related fused Heterocycles are of interest as potential bioactive molecules such as CNS depressant [1] Antiproliferative, antimicrobial and antitumor [2-10]. Also, pyrazolo[3,4- $d$ ]pyrimidines were identified as general class of adenosine receptor [11]. The present study described the synthesis and characterization of novel triazolopyrimidine and their fused.

\section{Experimental section :}

Melting points of all - the compounds are determined in open capillary method and are uncorrected. IR spectra are recorded in $\mathrm{KBr}$ pellets on schimadzu FT-IR affinity -1 -spectrometer. ${ }^{1} \mathrm{HNMR}$ and ${ }^{13} \mathrm{CNMR}$ spectra in DMSO $-\mathrm{d}_{6}$ solvent on Bruker High performance Digital FT-NMR Spectrometer. Avance cell $400 \mathrm{MHZ}$ using TMS as internal stander and Mass spectra were done in the regional center for mycology and biotechnology , Al-Azhar University .

Synthesis procedure of ethyl-1- phenyl-5-(1H-tetrazol-1-yl)-1H-pyrazole-4-carboxylate $(2)$ :

A mixture of $1(10 \mathrm{mmol})$, triethyl ortho formate $(10 \mathrm{mmol})$, and sodium azide $(10 \mathrm{mmol})$ in $40 \mathrm{ml}$ glacial acetic acid was stirred under reflux for $2 \mathrm{~h}$. The reaction mixture was cooled and suspended in $7 \mathrm{ml} \mathrm{Conc} \mathrm{HCl}$. The solid collected by suction filtration and washed with water. The crude product was recrystallized from ethanol to afford $\mathbf{2}$ (70 \%), m.p:122-124\% C;

\section{Spectroscopic data:-}

1. IR data $\left(\mathrm{cm}^{-1}\right): 3050(\mathrm{CH}-\mathrm{Ar}), 2920-2888(\mathrm{CH}-\mathrm{aliph}), 1710(\mathrm{C}=\mathrm{O})$

2. ${ }^{1} \mathrm{HNMR}\left(\mathrm{DMSO}-\mathrm{d}_{6}-\delta \mathrm{ppm}\right): 1.33\left(\mathrm{t}, 3 \mathrm{H}, \mathrm{CH}_{2} \mathrm{CH}_{3}, 5.8 \mathrm{HZ}\right), 4.28\left(\mathrm{q}, 2 \mathrm{H}, \mathrm{CH}_{2} \mathrm{CH}_{3}, \mathrm{~J}=7.1 \mathrm{HZ}\right), 7.31-7.88(\mathrm{~m}, 5 \mathrm{H}$, Ar-H), 8.23(s, $1 \mathrm{H}$, tetrazole $\mathrm{H}-5)$

3. ${ }^{13}$ CNMR : $20.2\left(\mathrm{CH}_{3}\right), 60.8\left(\mathrm{CH}_{2}\right), 110.5-149.5(\mathrm{Ar}-\mathrm{CH}), 166.7(\mathrm{C}=\mathrm{O})$

Corresponding Author:-Aisha Youssef Hassan.

Address:-Al-Azhar University, Faculty of Science, Girls ; Branch,Chemistry Department, Nasr City, 
Elemental Analysis:-

MS: $\mathrm{m} / \mathrm{z}(\%)=284.11$ (5.4). Anal .Calcd for : $\mathrm{C}_{13} \mathrm{H}_{12} \mathrm{~N}_{6} \mathrm{O}_{2},[\%$ calculated (\%found)]:- $\mathrm{C}=54.93(54.72), \mathrm{H}=4.25$ (4.00), $\mathrm{N}=29.56(29.12)$

Synthesis procedure of 5.6- Diamino-1-phenyl-1H-pyrazolo[3.4- $d]$ pyrimidin-4(5H)-one (3) :

Compound $2(10 \mathrm{mmol})$ in $15 \mathrm{ml}$ hydrazine hydrate was heated under reflux for $7 \mathrm{~h}$. The reaction mixture was cooled and suspended in $50 \mathrm{ml}$ water. The solid was collected by suction filtration, wash with water and recrystallized from ethanol to afford $\mathbf{3}(75 \%)$. m.p : $228-230^{\circ} \mathrm{C}$

\section{Spectroscopic data:-}

1. IR data $\left(\mathrm{cm}^{-1}\right): 3330,3290\left(2 \mathrm{NH}_{2}\right), 3055(\mathrm{CH}-\mathrm{Ar}), 1680(\mathrm{C}=\mathrm{O}), 1580(\mathrm{C}=\mathrm{N})$

2. ${ }^{1} \mathrm{HNMR}$ (DMSO- $\left.\mathrm{d}_{6}-\delta \mathrm{ppm}\right): 6.11$ ( br.s, $\left.2 \mathrm{H}, \mathrm{C}-\mathrm{NH}_{2}\right) ; 7.33-7.81(\mathrm{~m}, 5 \mathrm{H}, \mathrm{Ar}-\mathrm{H}), 11.2$ (b.r.s. $\left.2 \mathrm{H}, \mathrm{NH}_{2}\right)$

3. ${ }^{13} \mathrm{CNMR}: 121.3-149.5(\mathrm{Ar}-\mathrm{CH}), 1681(\mathrm{C}=\mathrm{O})$

Elemental Analysis:-

MS: M/Z $(\%)=243.01\left[\mathrm{M}^{+}\right](14.1)$. Anal. Calcd for : $\mathrm{C}_{11} \mathrm{H}_{10} \mathrm{~N}_{6} \mathrm{O}$, [\% calculated (\%found)]:- $\mathrm{C}=54.54$ (54.33), $\mathrm{H}$ $=4.16(4.00), \mathrm{N}=34.69(34.50)$

Synthesis procedure of ethyl-5-(2-(dicyano methylene)-1-phenyl-1H-pyrazole-4-carboxylate (4) :

A solution of compound 1 in Conc $\mathrm{HCl}(2 \mathrm{mmol}$ in $5 \mathrm{ml})$ was kept in in an ice bath at $0-5{ }^{\circ} \mathrm{C}$ for $10 \mathrm{~min}$. An aqueous solution of sodium nitrite $(2.1 \mathrm{mmol}$ in $5 \mathrm{ml})$ was added drop wise with stirring to the amine hydrochloride salt solution over period of $20-25 \mathrm{~min}$ at $0{ }^{\circ} \mathrm{C}$. A yellow precipitated of diazonium hydrochloride salt was formed . The reaction mixture was stirred for an additional $15 \mathrm{~min}$. While maintaining the temperature at $0{ }^{\circ} \mathrm{C}$. Malononitrile $(2 \mathrm{mmol})$ was added to a solution of the amine hydrochloride salt and $5 \mathrm{~g}$ anhydrous sodium acetate in $100 \mathrm{ml}$ ethanol with stirring at $0-5{ }^{\circ} \mathrm{C}$.Stirring was continued for an additional $3 \mathrm{~h}$. The mixture was left overnight in the refrigerator. Water $(250 \mathrm{ml})$ was added to the reaction mixture and the solid product was collected by filtration and recrystallized from ethanol to afford 4 (60\%); m.p: $150-152{ }^{\circ} \mathrm{C}$.

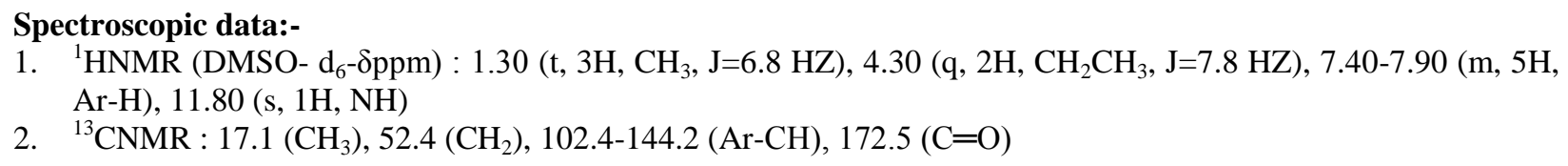

Elemental Analysis:-

MS: $\mathrm{m} / \mathrm{z}(\%)=308.12(8.11 \%)$. Anal.Calcd. for : $\mathrm{C}_{15} \mathrm{H}_{12} \mathrm{~N}_{6} \mathrm{O}_{2}$, [\% calculated (\%found)]:- $\mathrm{C}=58.44(58.10), \mathrm{H}=$ $3.92(3.50), \mathrm{N}=27.26(27.00)$

Synthesis procedure of E-5-[(3,5-Diamino-1H-pyrazol-4-yl-)diazo-nyl]-1-phenyl-1H-pyrazole-4carbohydrazide (5):

A mixture of $4(10 \mathrm{mmol})$ and hydrazine hydrate $(15 \mathrm{mmol})$ in $30 \mathrm{ml}$ ethanol was heated under reflux for $6 \mathrm{~h}$. The solid precipitated after concentration was filtrated, dried , and recrystallized from ethanol to afforded 5 (55\%); m.p: $278-280^{\circ} \mathrm{C}$.

Spectroscopic data:-

${ }^{1}$ HNMR (DMSO- $\mathrm{d}_{6}-\delta$ ppm) : 2.60,2.85, 4.20 (3s,6H , 3NH $)$ ), 7.40-7.91 (m, 5H, Ar-H), 9.80 ( br.s, 1H, NH), 10.12( br.s, $1 \mathrm{H}, \mathrm{NH})$

Elemental Analysis:-

MS: $\mathrm{m} / \mathrm{z}(\%)=326.1$ (4.1); Anal. Calcd .for : $\mathrm{C}_{13} \mathrm{H}_{14} \mathrm{~N}_{10} \mathrm{O}$, [\% calculated (\%found)]:- $\mathrm{C}=47.85$ (47.50), $\mathrm{H}=4.32$ (4.00), $\mathrm{N}=42.92(42.54)$

Synthesis procedure of 1-phenylbenzo[4,5]thiazolo[3,2-a]pyrazolo[3,4- $d]$ pyrimidine $(6)$ :

A solution of ortho -amino ester $\mathbf{1}(5 \mathrm{mmol})$ and 2-mercaptobenzo thiazole $(5 \mathrm{mmol})$ was heated to reflux temperature in dry acetic acid $(6 \mathrm{ml})$ for $6 \mathrm{~h}$. After cooling to room temperature ,crushed ice was added, and the mixture stirred for $1 \mathrm{~h}$. The separated product was collected and filtration and crystallized from methanol to afford 6 (50\%) ; m.p: $>360^{\circ} \mathrm{C}$. 
Spectroscopic data:-

IR data $\left(\mathrm{cm}^{-1}\right): 3033(\mathrm{CH}-\mathrm{Ar}), 1685(\mathrm{C}=\mathrm{O}), 1580(\mathrm{C}=\mathrm{N})$

Elemental Analysis:-

MS: $\mathrm{m} / \mathrm{z}(\%)=319.0(12.1)$; Anal.Calcd. for : $\mathrm{C}_{17} \mathrm{H}_{10} \mathrm{~N}_{4} \mathrm{O}$ S, [\% calculated (\%found)]:- $\mathrm{C}=64.14$ (64.00), $\mathrm{H}=3.17$ (3.12), $\mathrm{N}=17.60$ (17.22), $\mathrm{S}=10.07$ (10.12)

Synthesis procedure of amino-6-(chloromethyl)-1-phenyl-1H-pyrazolo[3,4- $d]$ pyrmidin-4-(5H)one $(8)$ :

A mixture of compound $7(0.01 \mathrm{~mol})$ and 2-chloroacetyl chloride $(10 \mathrm{mmol})$ were heated under reflux for $12 \mathrm{~h}$. The reaction mixture was cooled to room temperature and then poured on crushed ice with scratching, the mixture was acidified by $10 \% \mathrm{HCl}$ and allowed to stand overnight, the separated solid was filtrated off, washed thoroughly with water , dried and crystallized from ethanol to afford 8 (55\%); m.p: $>360^{\circ} \mathrm{C}$.

\section{Spectroscopic data:-}

1. IR data $\left(\mathrm{cm}^{-1}\right): 3300,3214\left(\mathrm{NH}_{2}\right), 3055(\mathrm{CH}-\mathrm{Ar}), 1680(\mathrm{C}=\mathrm{O}), 1580(\mathrm{C}=\mathrm{N})$

2. ${ }^{1} \mathrm{HNMR}$ (DMSO- $\left.\mathrm{d}_{6}-\delta \mathrm{ppm}\right): 3.70\left(\mathrm{~s}, 2 \mathrm{H}, \mathrm{CH}_{2}\right), 6.20\left(\mathrm{~s}, 2 \mathrm{H}, \mathrm{NH}_{2}\right)$ exchangeable $\left.\mathrm{D}_{2} \mathrm{O}\right), 7.28-7.85(\mathrm{~m}, 5 \mathrm{H}, \mathrm{Ar}-\mathrm{H})$, 8.27 (s,1H ,CH-pyrazole)

Elemental Analysis:-

MS: $\mathrm{m} / \mathrm{z}(\%)=277(5.56)$; Anal. Calcd : $\mathrm{C}_{12} \mathrm{H}_{10} \mathrm{ClN}_{5} \mathrm{O}(275.69)$, [\% calculated (\%found)]: $\mathrm{C}=58.28$ (52.18), $\mathrm{H}=$ $3.66(3.78), \mathrm{N}=25.40(25.30)$

Synthesis procedure of 8-amino-5-(chloromethyl)-3-phenyl-3H-dipyrazolo[1,5-c:4',3'-e]pyrimidin-9carbonitrile (9) :

Synthesis procedure of ethyl-5-(chloromethyl)-8-oxo-3-phenyl-7,8-dihydro-3H-dipyrazolo[1,5-c:4',3'e]pyramidin-9-carboxylate (10):

A equimolar of $\mathbf{8}(10 \mathrm{mmol})$ and malononitrile /or diethylmalonate $(10 \mathrm{mmol})$ was heated until the contents melted, the reaction mixture was maintained at temperature $180^{\circ} \mathrm{C}$ for $4 \mathrm{~h}$, the fused mass thus obtained was treated with ethanol, collected by filtration and recrystallized by Dioxane . Compound 9 (62\%); m.p:285-287 $\mathrm{C}$

\section{Spectroscopic data:-}

1. IR data $\left(\mathrm{cm}^{-1}\right): 3330,3280\left(\mathrm{NH}_{2}\right), 3032(\mathrm{CH}-\mathrm{Ar}), 2920(\mathrm{CH}-$ aliph$), 2222(\mathrm{C} \equiv \mathrm{N}), 1640(\mathrm{C}=\mathrm{N})$

2. ${ }^{1} \mathrm{HNMR}$ (DMSO- $\left.\mathrm{d}_{6}-\delta \mathrm{ppm}\right): 3.80\left(\mathrm{~s}, 2 \mathrm{H}, \mathrm{CH}_{2}\right), 5.80\left(\mathrm{~s}, 2 \mathrm{H}, \mathrm{NH}_{2}\right.$, exchangeable with $\left.\mathrm{D}_{2} \mathrm{O}\right), 7.33-8.11(\mathrm{~m}, 5 \mathrm{H}, \mathrm{Ar}-$ $\mathrm{H}) ;{ }^{13} \mathrm{CNMR}$ 55.1 $\left(\mathrm{CH}_{2}\right), 122(\mathrm{C} \equiv \mathrm{N}), 114-146(\mathrm{Ar}-\mathrm{CH})$

Elemental Analysis:-

MS: $\mathrm{m} / \mathrm{z}(\%)=323(1.1)$; Anal. Calcd : $\mathrm{C}_{15} \mathrm{H}_{10} \mathrm{ClN}_{7}$, [\% calculated (\%found)]: $\mathrm{C}=55.65$ (55.30), $\mathrm{H}=3.11(3.00)$, $\mathrm{N}=30.29(30.00)$

Compound 10 (60\%) ; m.p:240-242 ${ }^{\circ} \mathrm{C}$.

\section{Spectroscopic data:-}

1. IR data $\left(\mathrm{cm}^{-1}\right): 3280(\mathrm{NH}), 3032(\mathrm{CH}-\mathrm{Ar}), 2980(\mathrm{CH}-\mathrm{aliph}), 1710,1660(2 \mathrm{C}=\mathrm{O})$

2. ${ }^{1} \mathrm{HNMR}$ (DMSO- $\left.\mathrm{d}_{6}-\delta \mathrm{ppm}\right) 1.28\left(\mathrm{t}, 3 \mathrm{H}, \mathrm{CH}_{2} \mathrm{CH}_{3}, \mathrm{~J}=5.88 \mathrm{HZ}\right.$ ), 4.30(q, $2 \mathrm{H}, \mathrm{CH}_{2} \mathrm{CH}_{3}, \mathrm{~J}=7.23 \mathrm{HZ}$ ), 7.31-7.81(M, $5 \mathrm{H}, \mathrm{Ar}-\mathrm{H}), 9.88\left(\mathrm{~s}, 1 \mathrm{H}, \mathrm{NH}\right.$, exchangeable with $\left.\mathrm{D}_{2} \mathrm{O}\right) ;{ }^{13} \mathrm{CNMR}^{18.1}\left(\mathrm{CH}_{3}\right), 56.8\left(\mathrm{CH}_{2}\right), 62.4\left(\mathrm{CH}_{2}\right), 168,162$ $(2 \mathrm{C}=\mathrm{O}), 114-144(\mathrm{Ar}-\mathrm{CH})$

Elemental Analysis:-

MS: $\mathrm{m} / \mathrm{z}(\%)=374.08(4.0), 373.08$ (1.0). Anal. Calcd : Anal. Calcd : $\mathrm{C}_{17} \mathrm{H}_{14} \mathrm{ClN}_{5} \mathrm{O}_{3}$, [\% calculated (\%found)]: C $=54.92(54.50), \mathrm{H}=3.80(3.60), \mathrm{N}=18.84(18.50)$

Synthesis procedure of 2-(Cyanomethyl)-5-methyl-7-phenyl-pyrazolo[1,5-a]pyrimidine-3-carbonitrile (12): Synthesis procedure of 2-Amine -6-(cyanomethyl)-1H-imidazo[1,2-b]pyrazolo-7-carnonitrile (13) :

An equimolar amount of $11(10 \mathrm{mmol})$ and benzoylacetone / or chloro acetonitrile (10mmol)in ethanolic sodium ethoxide solution [(prepared by dissolving sodium metal $(0.24 \mathrm{~g}, 10 \mathrm{mmol})$ in absolute ethanol $(30 \mathrm{ml})]$ was heated under reflux for $12 \mathrm{~h}$. The reaction mixture was cooled to room temperature and then poured onto crushed ice with 
scratching , the mixture was acidified by $10 \% \mathrm{HCl}$ and allowed to stand overnight, the separated solid was filtered , washed with water, dried and crystallized from proper solvent .Compound 12 (70\%) ; m.p: 300-302 ${ }^{\circ} \mathrm{C}$.

\section{Spectroscopic data:-}

1. IR data $\left(\mathrm{cm}^{-1}\right): 3050$ (CH-Ar), 2993-2888(CH-aliph), 2222(2C $\left.\equiv \mathrm{N}\right)$

2. ${ }^{1} \mathrm{HNMR}$ (DMSO- $\left.\mathrm{d}_{6}-\delta \mathrm{ppm}\right): 1.14\left(\mathrm{~s}, 3 \mathrm{H}, \mathrm{CH}_{3}\right), 4.28\left(\mathrm{~s}, 2 \mathrm{H}, \mathrm{CH}_{2}\right), 7.28-7.71(\mathrm{~m}, 5 \mathrm{H}, \mathrm{Ar}-\mathrm{H}),{ }^{13} \mathrm{CNMR}^{2} 20.1\left(\mathrm{CH}_{3}\right)$, $56.7\left(\mathrm{CH}_{2}\right), 124.2,115.7(2 \mathrm{C} \equiv \mathrm{N}), 128.3-144.1(\mathrm{Ar}-\mathrm{CH})$

Elemental Analysis:-

MS: $\mathrm{m} / \mathrm{z}(\%)=273.29$ (17.4); Anal.Calcd: $\mathrm{C}_{16} \mathrm{H}_{11} \mathrm{~N}_{5}$, [\% calculated (\%found)]: $\mathrm{C}=70.32$ (70.00), $\mathrm{H}=4.06$ (4.01), $\mathrm{N}=25.63(25.30)$

Compound 13 (52\%) ; m.p: $280-282^{\circ} \mathrm{C}$.

\section{Spectroscopic data:-}

1. IR data $\left(\mathrm{cm}^{-1}\right): 3340,3300\left(\mathrm{NH}, \mathrm{NH}_{2}\right), 2220(2 \mathrm{C} \equiv \mathrm{N})$

2. ${ }^{1} \mathrm{HNMR}$ (DMSO- $\left.\mathrm{d}_{6}-\delta \mathrm{ppm}\right): 5.82\left(\mathrm{~s}, 2 \mathrm{H}, \mathrm{NH}_{2}\right.$, exchangeable with $\left.\mathrm{D}_{2} \mathrm{O}\right), 4.11\left(\mathrm{~s}, 2 \mathrm{H}, \mathrm{CH}_{2}\right), 8.12(\mathrm{~s}, 1 \mathrm{H}, \mathrm{CH}-$ imidazole), $12.18\left(\mathrm{~s}, 1 \mathrm{H}, \mathrm{NH}\right.$, exchangeable with $\left.\mathrm{D}_{2} \mathrm{O}\right)$

\section{Elemental Analysis:-}

MS: $\mathrm{m} / \mathrm{z}(\%)=186.1(7.7)$; Anal.Calcd: $\mathrm{C}_{8} \mathrm{H}_{6} \mathrm{~N}_{6},[\%$ calculated (\%found) $]: \quad \mathrm{C}=51.61(51.30), \mathrm{H}=3.25(3.00), \mathrm{N}$ $=45.14(45.00)$

\section{Synthesis procedure of 6-(cyanomethyl)-2-methyl-3-oxo-3H-imidazo[1',2':3,4]imidazo[1,2-b]pyrazole-5-} carbonitrile (14):

A equimolar mixture of $\mathbf{1 3}(10 \mathrm{mmol})$ and pyruvic acid $(10 \mathrm{mmol})$ was heated until the contents melt . The reaction mixture was maintained at temperature $200{ }^{\circ} \mathrm{C}$ for $4 \mathrm{~h}$. The fused mass thus obtained was treated with ethanol, collected by filtration and recrystallized from dioxane to afford 14 (55\%); ; m.p:>360 ${ }^{\circ} \mathrm{C}$.

\section{Spectroscopic data:-}

1. IR data $\left(\mathrm{cm}^{-1}\right): 2988(\mathrm{CH}-$ aliph $), 2211(2 \mathrm{CN}), 1670(\mathrm{C}=\mathrm{O})$

2. ${ }^{1} \mathrm{HNMR}$ (DMSO- $\left.\mathrm{d}_{6}-\delta \mathrm{ppm}\right): 1.82\left(\mathrm{~s}, 3 \mathrm{H}, \mathrm{CH}_{3}\right), 4.28\left(\mathrm{~s}, 2 \mathrm{H}, \mathrm{CH}_{2}\right), 8.22$ (s, 1H, CH-imidazole)

\section{Elemental Analysis:-}

MS: $\mathrm{m} / \mathrm{z}(\%)=239 . .20\left[\mathrm{M}^{+}\right](8.21)$; Anal.Calcd: $\mathrm{C}_{11} \mathrm{H}_{6} \mathrm{~N}_{6} \mathrm{O}$, [\% calculated (\%found)]: $\mathrm{C}=55.46(55.30), \mathrm{H}=2.54$ $(2.50), \mathrm{N}=35.28(35.20)$

Synthesis procedure of 2-(Cyanomethyl)-9-methyl-5,6,7,8-tetrahydropyrazolo[5,1-b]quinazoline-3carbonitrile (16):

A mixture of $11(1 \mathrm{mmol})$ and acetylcyclohexanone $(1 \mathrm{mmol})$ was added to $5 \mathrm{ml}$ of acetic acid, the solution diluted was reflux for $10 \mathrm{~h}$, cooled to room temperature, evaporated to dryness, the residue was washed with water and alcohol, dried and crystallized from acetic acid to afford 16 (62\%); m.p: $234-236^{\circ} \mathrm{C}$

1. IR data $\left(\mathrm{cm}^{-1}\right): 2981-2833(\mathrm{CH}-$ aliph $), 2218(2 \mathrm{CN}), 1550(\mathrm{C}=\mathrm{C})$;

2. ${ }^{1} \mathrm{HNMR}\left(\mathrm{DMSO}-\mathrm{d}_{6}-\delta \mathrm{ppm}\right): 2.32\left(\mathrm{~s}, 2 \mathrm{H}, \mathrm{CH}_{2}\right), 2.58\left(\mathrm{~s}, 2 \mathrm{H}, \mathrm{CH}_{2}\right), 3.01\left(\mathrm{t}, \mathrm{t}, \mathrm{CH}_{2}, \mathrm{~J}=7.3 \mathrm{HZ}, \mathrm{J}=1.4 \mathrm{HZ}\right), 3.56(\mathrm{t}, \mathrm{t}$, $\left.2 \mathrm{H}, \mathrm{CH}_{2}, \mathrm{~J}=7.6 \mathrm{HZ}, \mathrm{J}=2.8 \mathrm{HZ}\right), 4.18\left(\mathrm{~s}, 2 \mathrm{H}, \mathrm{CH}_{2}\right)$

3. $\left.{ }^{13} \mathrm{CNMR}: 14.46\left(\mathrm{CH}_{3}\right), 21.91\left(\mathrm{CH}_{2}\right), 22.54\left(\mathrm{CH}_{2}\right) 29.6\left(\mathrm{CH}_{2}\right), 29.9 \mathrm{CH}_{2}\right) 44.2\left(\mathrm{CH}_{2} \mathrm{CN}\right)$

Elemental Analysis:-

MS: $\mathrm{m} / \mathrm{z}(\%)=251.22(11.0)$; Anal.Calcd: $\mathrm{C}_{14} \mathrm{H}_{13} \mathrm{~N}_{5}$, [\% calculated (\%found)]: $\mathrm{C}=66.92$ (66.50), $\mathrm{H}=5.21(5.00)$, $\mathrm{N}=27.87(27.60)$

\section{Results and discussion:-}

Treatment of Ethyl-5-amino-1- phenyl -1H- pyrazole-4-carboxylate

[11] with tri ethyl ortho formate and sodium azide afforded ethyl-1-phenyl-5-(1H-tetrazol-1-yl)-1H-pyrazole-4carboxylate 2 in good yield. The ${ }^{1} \mathrm{HNMR}$ of 2 showed a singlet signal at $\delta 8.23 \mathrm{ppm}$ characteristic of tetrazole 
proton, and a lack of the amino proton signal detected for the parent $\mathbf{1}$, Pyrazolopyrimidine derivatives $\mathbf{3}$ was obtained by refluxing $\mathbf{2}$ with hydrazine hydrate. The reaction sequence and mechanism are outlined in scheme $\mathbf{1}$ [12]. The ${ }^{1}$ HNMR of 3 revealed two exchangeable broad singlet signals at $\delta 6.11$ and 11.12 ppm for two amino groups, without the ester proton signals detected for the parent 2 .Compound $\mathbf{1}$ was diazotized hydrochloric acid and sodium nitrile. The desired diazonium chloride was then coupled with malononitrile to yield the corresponding azo derivatives $4 .{ }^{1} \mathrm{HNMR}$ of 4 showed the absence of an amino signal and the presence of signals at $\delta 1.30$ and $4.30 \mathrm{ppm}$ for ethyl ester group and $\delta 11.30 \mathrm{ppm}$ for an exchangeable $\mathrm{NH}$ proton. Hydrazone 4 reacted with hydrazine hydrate in ethanol under reflux to afford hydrazide $\mathbf{5} .{ }^{1} \mathrm{HNMR}$ of $\mathbf{5}$ exhibited signals at $\delta 2.60,2.85$ and $4.20 \mathrm{ppm}$ (exchangeable $\mathrm{NH}_{2}$ and $\mathrm{NH}$ protons). Tetracyclic condensed systems in one step via a double displacement process [13] using 2-methylthio-benzothiazole with ortho amino ester $\mathbf{1}$ gave 6. The mass spectrum of 6 showed the ion peak at $\mathrm{m} / \mathrm{z}(\%)=319.0(12.1)$ in accordance with the molecular weight $\left(\mathrm{C}_{17} \mathrm{H}_{10} \mathrm{~N}_{4} \mathrm{OS}\right)$.

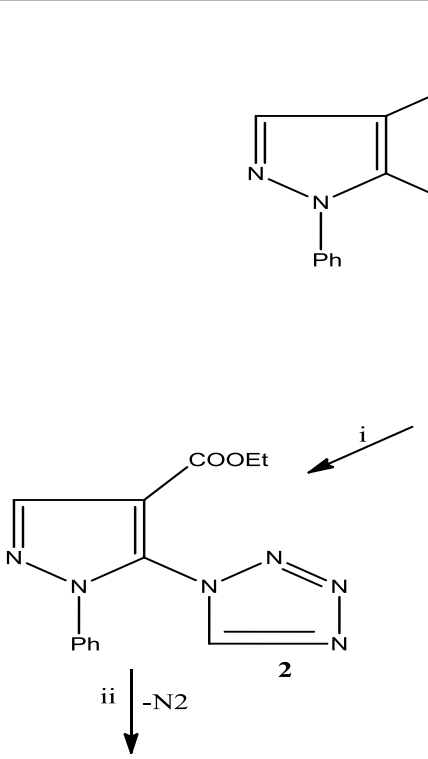<smiles>CCOC(=O)c1cnn(-c2ccccc2)c1N=C(C)N</smiles><smiles>CCOC(=O)c1cnn(-c2ccccc2)c1NN=C(C#N)C#N</smiles><smiles>N#Cc1c(CN)cnn1-c1ccccc1</smiles><smiles></smiles><smiles>NC(=O)c1cnn(-c2ccccc2)c1N=Nc1c(N)n[nH]c1N</smiles>

Scheme 1

Reagents and conditions : i)triethylorthof ormate, NaN3, gl.AcOH.ii) N2H4 iii) Malononitrile, $\mathrm{NaNO} 2 / \mathrm{HCl}$. iv) N2H4.v)

Moreover, one-pot cyclocondensation of hydrazide $\gamma 7$ [11] with 2-chloroacetyl chloride could be carried out by refluxing in sodium ethoxide to yield pyrazolopyrimidine $\gamma \mathbf{8}$ (scheme 2). ${ }^{1}$ HNMR of $\mathbf{8}$ showed a singlet at $\delta 3.70$ ppm integrated for two protons of $\left(\mathrm{CH}_{2}\right)$, in addition deuterium oxide exchangeable singlet signal at $\delta 6.20 \mathrm{ppm}$ due to $\mathrm{NH}_{2}$ protons . pyrazole-pyrimidine $\mathbf{8}$ was utilized in preparing the target compounds pyrazoloimiazopyrimidine derivatives 9 and $\mathbf{1 0}$, through fused with malononitrile /or diethylmalonate ${ }^{1} \mathrm{HNMR}$ of $\mathbf{9}$ recorded a singlet signal at $\delta 3.80 \mathrm{ppm}$ for $\left(\mathrm{CH}_{2}\right)$ and deuterium oxide exchangeable singlet signal at $\delta 5.80 \mathrm{ppm}$ due to NH2 proton. ${ }^{1} \mathrm{HNMR}$ of 10 showed signals at $\delta 1.28$ and 4.30 ppm corresponding to $\left(\mathrm{CH}_{2} \mathrm{CH}_{3}\right.$-ester $)$ and deuterium oxide exchangeable 
singlet signals at $\delta 9.88 \mathrm{ppm}$ corresponding to $\mathrm{NH}$ proton, whereas ${ }^{13} \mathrm{CNMR}$ of $\mathbf{1 0}$ refers to the presence of $\mathrm{CH}_{2}$ signals at $\delta 56.8 \mathrm{ppm}$ and carbonyl group at $\delta 162.2 \mathrm{ppm}$ and $168.1 \mathrm{ppm}$.

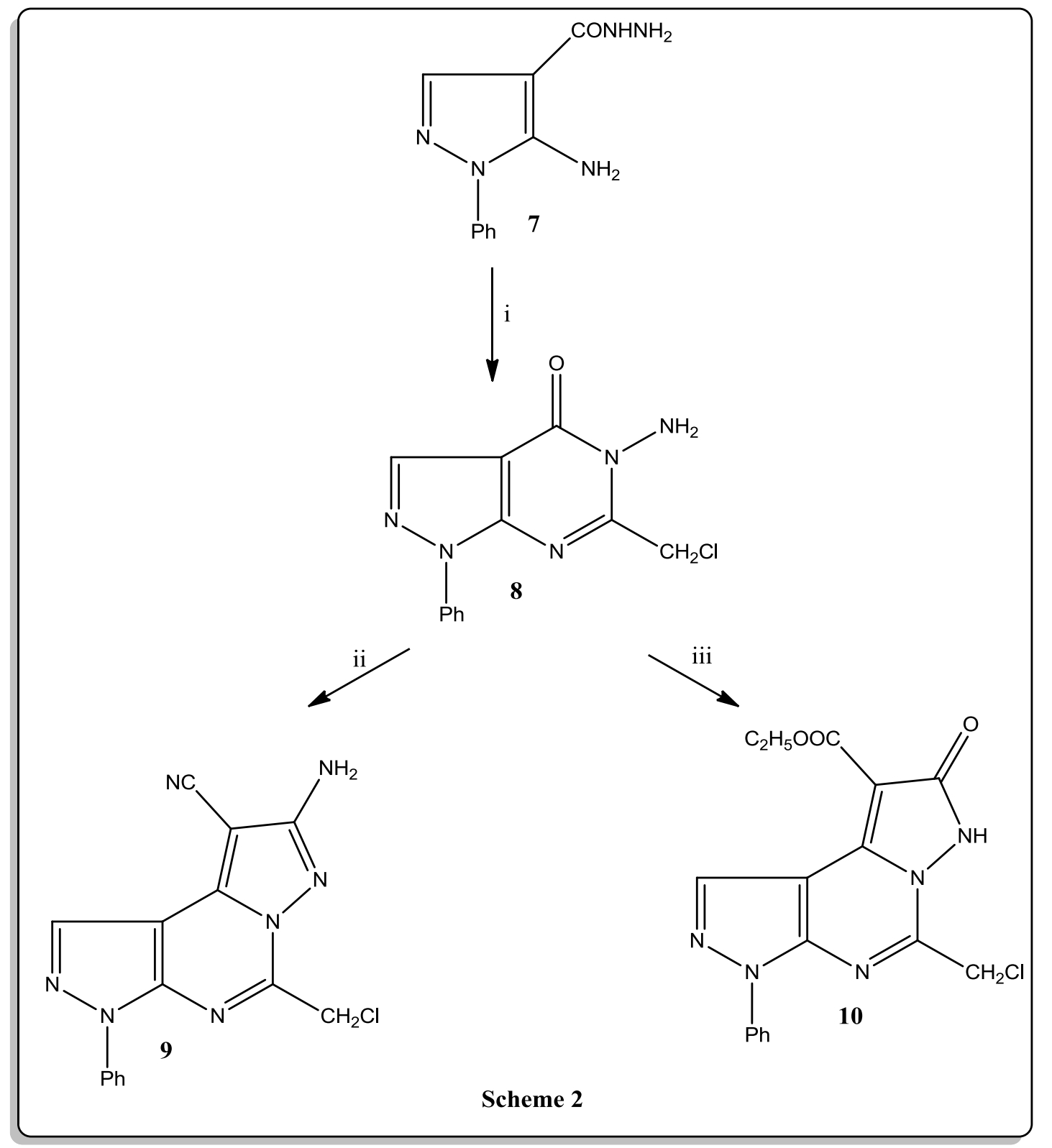

\section{Reagents and conditions : i) 2- chloroacetyl chloride . ii)Malononitrile. iii) Diethyl malonate.}

Our study were extended to synthesis fused azole (scheme 3). Thus, fusion of compound 11[14] with benzoyl acetone / or chloroacetonitrile furnished pyrazolopyrimidine $\mathbf{1 2}$ and pyrazoloimidazole $\mathbf{1 3}$, ${ }^{1} \mathrm{HNMR}$ of 12 revealed the presence of two singlet signals at $\delta 1.14$ and $4.28 \mathrm{ppm}$ for $\mathrm{CH}_{3}$ and $\mathrm{CH}_{2}$ groups, while ${ }^{13} \mathrm{CNMR}$ refers to the presence of $\mathrm{CH}_{3}, \mathrm{CH}_{2}$ and $(2 \mathrm{CN})$ groups at $\delta 20.1,56.7$ and $(124.7,115.7)$. ${ }^{1} \mathrm{HNMR}$ of $\mathbf{1 3}$ showed the presence of two singlet signals at $\delta 5.82$ and $12.18 \mathrm{ppm}$ due to $\mathrm{NH}_{2}$ and $\mathrm{NH}$ protons .Cyclization of $\mathbf{1 3}$ with pyruvic acid afforded imidazo[1',2':3.4]imidazo[1,2-b]pyrazole derivatives $\mathbf{1 4} .{ }^{1}$ HNMR of $\mathbf{1 4}$ showed the absence of an $\mathrm{NH}_{2}$ and $\mathrm{NH}$ protons, whereas ${ }^{13} \mathrm{CNMR}$ refers to the presence of signals at $\delta 18.1,54.6,115.1,125.2$ and $172.8 \mathrm{ppm}$ for $\mathrm{CH}_{3}, \mathrm{CH}_{2}, 2 \mathrm{CN}$ and carbonyl groups. 
Finally, reaction of 5-amino-3-(cyanomethyl)-1H-pyrazole-4-carbonitrile 11 with 2-acetylcyclohexanone [15] under reflux in presence of acetic acid afforded pyrazolo [5,1-b]quinazoline derivatives $16,{ }^{1} \mathrm{H}$ and ${ }^{13} \mathrm{C}$ NMR were used to deduce the structure of $\mathbf{1 6}$ (see experimental).

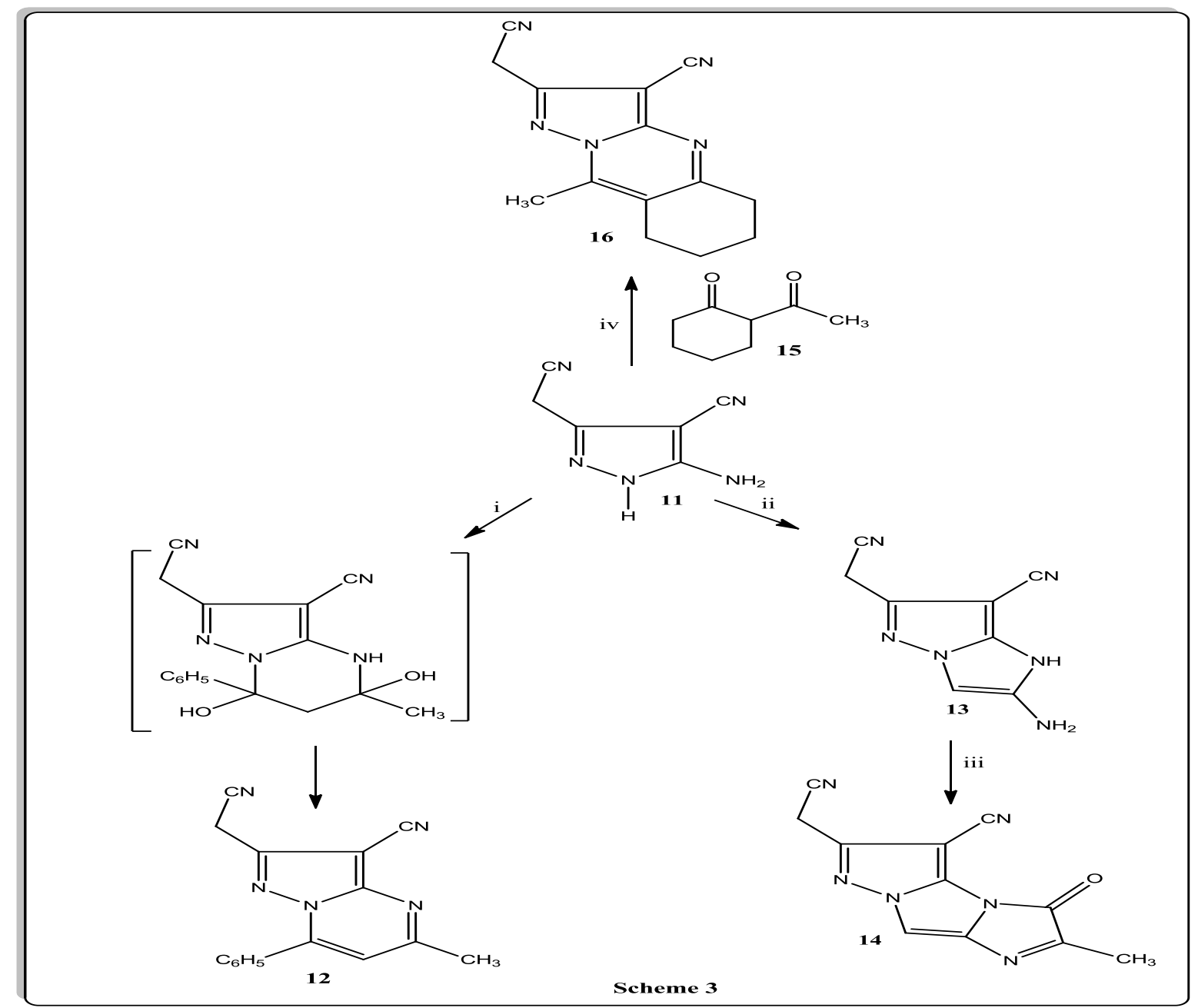

Reagents and conditions :i)PhCOCH $\mathrm{CHCH}_{3}$ ii) 2-Chloroacetonitrile .iii) 2-Oxopropanoic acid .

\section{References:-}

1. Neustadt, BR.; Hao, J.; Lindo, N.; Greenlee, W. J.; Tamforod, A. W.; Tulshina ,D.; Ongini, E. ; Hunter, J.; Monopoli, A.; Bertoell, R.; Foster, A.; Arik, L.; Lachowicz, J.; Nga, k.; Feng, K. I. Potent, Selective and orally active adenosine $\mathrm{A}_{2 \mathrm{~A}}$ receptor antagonists; aryl piperazine derivatives of pyrazolo[4,3-e]-1,2,4-triazolo[1,5c]pyrimidines ; Bioorg Med .Chem. Lett, (2007),17: 1376-1380.

2. Devarakonda, M.; Doonaboina, R.; Vanga,S.; Vemu, J.; Boni,S.; Mailavaram, R. P.; Synthesis of novel 2-alkyl4-substituted -amino-pyrazolo[3,4-d]pyrimidine as new leads for bacterial and anti-cancer activity. J. Med. Chem. Res, (2013), $22: 1090-1101$.

3. Abd Razik, H.A.; Abdel-Wahab, A. E. (2011) : Synthesis and biological evalution of some novel fused pyrazolopyrimidines as potential anticancer and antimicrobial agents . Arch. Pharm., 344: 184-196.

4. Ahmed, O. H.; Mohamed, M. A.; Ahmed, R. R.; Ahmed, S. A. (2009) :Synthesis and anti-tumor activities of some new pyridines and pyrazolo[1,5-a]pyrimidines. Eur. J. Med. Chem., 44: 3519-3523.

5. Deshmukh, S.; Dingor, K.; Gailkwad, V.; Jachak, M. (2016), An efficient Synthesis of pyrazolo[1,5a]pyrimidines and evalution of their antimicrobial activity, . J. Chem. Sci., 128: 1459-1468. 
6. Hassan, A. S.; Hefez, T.S.; Osman, S. A. (2015) : Synthesis, characterization and cytotoxicity of some new 5 aminopyrazole and pyrazolo[1,5-a]pyrimidine derivatives . Sci. Pharm., 83: 27-39.

7. Hassan,A . S .; Hefez, T. S.; Osman. S. A. M.; Ali, M. M.(2015) : Synthesis and in vitro cytotoxic activity of novel pyrimidines and related Schiff bases . Turk. J. Chem., 39: 1102-1113.

8. Hassan, A. S.; Mady, M. F.; Awad, H. M.; Hafez, T. S. ( 2017) :Synthesis and antitumor activity of some new pyrazolo[1,5-a]pyrimidines .Chin. Chem. Let., 28: 388-393.

9. Hassan SA, Masoud MD, Sroor MF, Askar AA. J. ( 2017) Synthesis and biological evalution of pyrazolo[1,5a]pyrimidine-carboxamideassantimicrobial agents. J. Med. Chem. Res., 26: 2909-2919.

10. 10.Quinn, R. J . ; Poulsen, S. (1996) : Pyrazolo[3,4-d]pyrimidine : C4, C6 substitution leads to adenosine $A_{1}$ receptor selectivity . Bioorg. Med. Chem. Lett., 6: 357-360.

11. Li,J. F.; Zhu, Y. Q.; Waug, X.; Yaug, H. Z. (2007) : Synthesis and herbicidal activities of some of di (aminopyrazole) ketone derivatives. J. Heterocyclic chem., 44: 749-755.

12. Abu-Hashem, A,A.; Abu-Zied, M.k.; El-Shehry, M.F. (2011) : Synthetic utility of bifunctional thiophene derivatives and antimicrobial evaluation of the newly synthesized agents ; Monatsh Chem ., 142: 539-545.

13. Chowdhury, A. Z. M.; Shibata, Y. (2001) : Synthesis of fused pyrimidines with N-, S- Heterocyclic Moieties by double -annelation reaction. J Heterocyclic Chem ., 38: 743-747.

14. Al najjar, A. R.; Gheath, H. A. (2014) : comparison of two routes for synthesis -5-aminopyrazole derivative. J. Chem. Pharm. Res., 6(7): 1426-1431.

15. Petrov, A. A,; Kasatochkin, A. N.; Emelina, E. E. (2011) : study of Regioselectivity of Reaction between 3(5)Aminopyrazoles and 2-Acetylcycloalkauoues. Russian Journal of organic chemistry ., 48(8): 1111-1120. 